\title{
Special Edition Interview with Dr. Jacinthe Pepin I Édition spéciale - Entrevue avec Dre Jacinthe Pepin
}

\author{
Sioban Nelson \\ University of Toronto, sioban.nelson@utoronto.ca \\ Pauline Paul \\ University of Alberta, ppaul@ualberta.ca
}

Follow this and additional works at: https://qane-afi.casn.ca/journal

Part of the Nursing Commons, and the Scholarship of Teaching and Learning Commons

\section{Recommended Citation}

Nelson, Sioban and Paul, Pauline (2020) "Special Edition Interview with Dr. Jacinthe Pepin | Édition spéciale - Entrevue avec Dre Jacinthe Pepin," Quality Advancement in Nursing Education - Avancées en formation infirmière: Vol. 6: Iss. 2, Article 11.

DOI: https://doi.org/10.17483/2368-6669.1271

This Interview is brought to you for free and open access by Quality Advancement in Nursing Education - Avancées en formation infirmière. It has been accepted for inclusion in Quality Advancement in Nursing Education - Avancées en formation infirmière by an authorized editor of Quality Advancement in Nursing Education - Avancées en formation infirmière. 


\section{Special Edition Interview with Dr. Jacinthe Pepin}

Interviewee: Dr. Jacinthe Pepin

Interviewers: Dr. Sioban Nelson \& Dr. Pauline Paul

Dr. Nelson: Thank you Jacinthe for being a part of this. We feel it's important that we have something in the special issue that addresses the enormous importance of the Université de Montréal and its role in nursing education. We thought it might not be fully appreciated, especially in Anglophone Canada, so we wanted to speak about that. Could you give us your thoughts on nursing in Montreal and the evolution and the factors that lead to the Faculté des sciences infirmières (Faculty of Nursing) at the Université de Montréal.

Dr. Pepin: Thank you for having me to talk about the history of nursing education in Montreal and Quebec, and the role of the Université de Montréal in that history. While I am not a historian, I have contributed to the Université de Montréal history of the Faculty of nursing with Y. Cohen and E. Lamontagne, who are historians (2002).

Dr. Paul: It's an excellent book.

Dr. Pepin: It's great to have the perspective of historians to study the creation of our Faculty. I should start with the importance of the ancestors that came before the Faculty of nursing: the Institut Marguerite d'Youville (IMY). It was founded in 1934 by the Sisters of Charity of Montreal, also called the Grey Nuns. They started this school in response to the Weir commission in 1932, which was on nursing recruitment and education, and which concluded that nursing education should be through university. So the Grey Nuns created this Institute, and they made sure it was affiliated with Université de Montréal. The nuns thought that it was important to educate nurses at the highest quality level, and they devoted their time to teaching girls and women. In fact, I think these nuns in Quebec were early

\section{Édition spéciale - Entrevue avec $D^{\text {re }}$ Jacinthe Pepin}

Invitée : $D^{\text {re }}$ Jacinthe Pepin

Intervieweuses : $D^{\text {re }}$ Sioban Nelson et $D^{\text {re }}$ Pauline Paul

$D^{\text {re }}$ Nelson : Merci de votre participation, Jacinthe. Dans ce numéro spécial, nous pensons qu'il est important de traiter de l'énorme importance et du rôle de l'Université de Montréal dans la formation en sciences infirmières. Selon nous, elle n'est pas pleinement valorisée, surtout au Canada anglophone, alors nous voulions en parler. Pourriez-vous nous faire part de vos réflexions sur les soins infirmiers à Montréal? Nous aimerions également entendre ce que vous avez à dire sur l'évolution et les facteurs qui ont conduit à la mise sur pied de la Faculté des sciences infirmières de l'Université de Montréal.

$D^{r e}$ Pepin : Merci de m'avoir invitée à parler de l'histoire de la formation en sciences infirmières à Montréal et au Québec, ainsi que du rôle que l'Université de Montréal y a joué. Bien que je ne sois pas historienne, $\mathrm{j}$ 'ai contribué à reconstituer l'histoire de la Faculté des sciences infirmières de l'Université de Montréal avec les historiennes Yolande Cohen et Esther Lamontagne (Les sciences infirmières, genèse d'une discipline, 2002).

$D^{\text {re }}$ Paul : Ce livre est excellent.

$D^{\text {re }}$ Pepin : J'ai particulièrement apprécié pouvoir compter sur les points de vue des historiens lors de mes recherches concernant la création de notre faculté. Commençons par l'importance des ancêtres de la Faculté des sciences infirmières: l'Institut Marguerite d'Youville (IMY). Cet établissement a été fondé en 1934 par les Sœurs de la Charité de Montréal, mieux connues comme les Sœurs Grises, en réponse à la commission Weir de 1932, qui portait sur le recrutement et la formation des infirmières, et qui a conclu que 
feminists, as they thought that it was important to educate girls and women.

Dr. Paul: I would agree with you, Jacinthe. I would add that the fact that they were across Canada influenced their thinking on nursing education. I know that at the Edmonton General Hospital they were connected to what was going on in $\mathrm{BC}$.

Dr. Nelson: The Grey Nuns were networked across the country. Did they have nursing schools across the country?

Dr. Paul: They had hospitals and hospital schools. For example, in the 1960s the faculty at the hospital school in Edmonton run by the Grey Nuns were better educated than the faculty at the University of Alberta.

Dr. Nelson: I'm not surprised, but I hadn't realized. Was there a particular individual in Montreal that really forged it ahead? Were there certain sisters? It would be good to give them a name.

Dr. Pepin: Sister Allaire was the director of the Institute. She was an honorary fellow of the American Group of Hospital Administrators. She was an administrator, but she played an important role in deciding where nursing should go. She was elected by the earliest version of CASN., the Canadian Conference of University Schools of Nursing, as the vice president at their first meeting in 1942.

Another figure was Sister Denise Lefebvre. She held a doctorate in pedagogy from the Université de Montréal. She was the first Canadian nurse actually to obtain a doctorate in pedagogy. She had studied at St Boniface Hospital in Manitoba for her diploma but got licensed at the Catholic University in Washington. She directed a book called the Le soin des malades, first published in 1944. She right away set the tone for nursing and what would be taught, what the students needed to know. la formation en sciences infirmières devait se faire à l'université. Les Sœurs Grises ont alors créé cet établissement, s'assurant qu'il soit affilié à l'Université de Montréal. Les religieuses pensaient qu'il était important de former les infirmières au plus haut niveau de qualité qui soit, et elles consacraient leur temps à enseigner aux filles et aux femmes. En fait, je pense que ces religieuses du Québec étaient les premières féministes, car pour elles il était primordial que les filles et les femmes reçoivent une éducation.

$D^{\text {re }}$ Paul : Je partage cette opinion, Jacinthe. J'ajouterais que leur présence à l'échelle du Canada a influencé leur réflexion sur la formation en sciences infirmières. Je sais que les Sœurs Grises de l'Edmonton General Hospital suivaient ce qui se passait en Colombie-Britannique.

$D^{\text {re }}$ Nelson : Les Sœurs Grises appartenaient à un réseau national. Y avait-il des écoles de sciences infirmières partout au pays?

$D^{\text {re }}$ Paul : Elles avaient des hôpitaux et des écoles de sciences infirmières en milieu hospitalier. Par exemple, dans les années 1960, le corps professoral de l'école hospitalière d'Edmonton dirigées par les Sœurs Grises était plus instruit que celui de la University of Alberta.

$D^{\text {re }}$ Nelson : Bien que je ne le savais pas, je ne suis pas surprise. Y a-t-il une personne en particulier à Montréal qui a vraiment fait avancer les choses? Certaines religieuses? Ce serait bien d'avoir leurs noms.

$D^{\text {re }}$ Pepin : L'Institut était géré par Sœur Allaire, qui était membre honoraire d'un groupe américain d'administrateurs d'hôpitaux, le American Group of Hospital Administrators. En plus d'être administratrice, elle a joué un rôle important pour donner une direction aux soins infirmiers. Le précurseur de l'ACESI, la Canadian Conference of University Schools of Nursing (colloque canadien des écoles 
Those two sisters were ahead of things. The Grey Nuns were ahead globally, and they were aware of the medical situation in the Americas - for example, health care specialities. They were very much aware and adapted their programs to prepare nurses accordingly to the evolution occurring. In the early 1950s, Denise Lefebvre had a conversation with the Rector of the Université de Montréal to discuss creating a faculty of nursing. They would have been offering a master's degree at this new faculty as a continuation of the baccalaureate level the nuns were offering at the IMY. This didn't happen quite as they had thought because there was an existing project for a university hospital. This project was led by the dean of the Faculty of medicine and the Hôpital St Luc's physicians and the director of nursing, Alice Girard, who was also associate administrator. They were thinking that a faculty of nursing was needed, because in a university hospital, nurses need to be prepared at the university level. These two plans were made in parallel. Finally, the Faculty of Nursing was created in 1962 with Alice Girard as the founding Dean. That same year, the Grey Nuns created the first baccalaureate as entry-to-practice program at the IMY. It is interesting that those two important events for nursing in Montreal happened at the same time in two different sites. Alice Girard was a public health nurse who had a degree in hospital administration from Johns Hopkins University. She was the director of nursing for 10 years at the Hôpital St Luc and became the dean of the Faculty of nursing, Université de Montréal in 1962. Her good relationship with Dr Bonin, Dean at the Faculty of medicine and the fact she was a lay public health nurse were likely factors in her appointment as the dean. The first speciality for nurses was public health nursing, which was taught mainly by nurses and also by some physicians at l'École d'Hygiène. At the Université de Montréal between 1940-1980 the nurses were the largest group of women at the university (Cohen et al., 2002). universitaires de sciences infirmières), l'a élue vice-présidente lors de sa première réunion en 1942.

Il y avait aussi Sœur Denise Lefebvre, qui détenait un doctorat en pédagogie de l'Université de Montréal. Première infirmière canadienne à se voir conférer ce diplôme, elle a étudié à l'Hôpital SaintBoniface du Manitoba pour l'obtenir, mais a obtenu sa licence à la Catholic University de Washington. Elle a supervisé la rédaction d'un livre, Le soin des malades, publié pour la première fois en 1944, livre qui lui a permis d'immédiatement donner le ton aux soins infirmiers et à ce qui serait enseigné, jetant les fondements de ce que les étudiantes devaient savoir.

Ces deux religieuses étaient visionnaires. Les Sœurs Grises étaient des précurseures à l'échelle mondiale. Elles connaissaient la situation médicale en Amérique du Nord (par exemple, les domaines spécialisés des soins de santé). Elles étaient très conscientes de ce qui se passait et se sont servies de leurs connaissances pour adapter leurs programmes afin qu'ils préparent les infirmières en fonction de l'évolution du paysage des soins de santé. Au début des années 1950, Denise Lefebvre a discuté avec le recteur de l'Université de Montréal de la création d'une faculté des sciences infirmières. Les Sœurs Grises voulaient offrir une maîtrise dans cette nouvelle faculté pour faire suite au niveau du baccalauréat que les religieuses offraient à l'IMY. Les choses ne se sont pas passées exactement comme elles le voulaient, car un projet pour un hôpital universitaire était déjà en branle. Ce projet était mené par le doyen de la Faculté de médecine et les médecins de l'Hôpital Saint-Luc ainsi que par la directrice des soins infirmiers, Alice Girard, également administratrice associée. Les Sœurs Grises pensaient qu'une faculté des sciences infirmières était nécessaire, car dans un hôpital universitaire, les infirmières doivent 
Dr. Paul: Mentioning Alice Girard is so important, so I was wondering if you could tell us a little about the new campus, where they named the main square after her. And the other thing was her connection with the wider community. When there was the Royal Commission on Health Services, she was the only nurse, the only woman, and the only French speaker who sat on the commission. She may have been on the commission as well because Emmett Hall, who was leading it, had been the lawyer for the Grey Nuns in Saskatchewan. There were all these connections. She even became the president of ICN later on.

Dr. Pepin: You are right, Montreal named the main square of the Université de Montréal new campus after Alice Girard, the first woman dean--it's wonderful - to celebrate her pioneer work in nursing, health administration and university administration. The fact that she was completely bilingual - born in Connecticut in a French-Canadian family - helped her to be part of discussion across Canada and the United States as well, and then at an international level.

I met Alice Girard in the last years of her life and there was a story in particular that she liked to tell. Being close to Dr Bonin, dean of medicine, they presented together the request for the creation of a faculty of nursing. She liked to think that some faculties representatives on the Board didn't realize what happened, because they eventually questioned it-nursing wasn't considered a scientific discipline, though it was too late.

Dr. Paul: Is this a nursing urban legend? I had also heard that the Grey Nuns wouldn't let the institute go unless it became a faculty.

Dr. Pepin: The Grey Nuns had done some benchmarking in Canada and in the United States to found out if it was preferable to continue as an independent school, to become a faculty, or to become a school within a faculty, and in that case of which faculty. They concluded that a faculty, independent from être préparées au niveau universitaire. Ces deux projets ont donc été réalisés parallèlement. Enfin, la Faculté des sciences infirmières (appelée la Faculté de Nursing à l'époque) a été créée en 1962; Alice Girard en était la doyenne fondatrice. Cette même année, les Sœurs Grises ont créé le premier baccalauréat comme programme pour accéder à la pratique à l'IMY. Il est intéressant de constater que ces deux événements importants pour les sciences infirmières à Montréal se sont déroulés en même temps à deux endroits différents. Alice Girard était une infirmière de la santé publique diplômée en administration hospitalière de la Johns Hopkins University. Elle a occupé le poste de directrice des soins infirmiers pendant 10 ans à l'Hôpital SaintLuc et est devenue doyenne de la Faculté des sciences infirmières de l'Université de Montréal en 1962. Sa nomination comme doyenne découle probablement de ses bonnes relations avec le $\mathrm{D}^{\mathrm{r}}$ Bonin, doyen de la Faculté de médecine, et du fait qu'elle était infirmière laïque en santé publique. La première spécialité des infirmières était les soins infirmiers en santé publique, principalement enseignés par des infirmières, mais aussi par certains médecins de l'École d'hygiène. À l'Université de Montréal, entre 1940 et 1980, les infirmières constituaient le plus grand groupe de femmes à l'université (Cohen et al., 2002).

$D^{\text {re }}$ Paul : Il est si important de mentionner Alice Girard. Elle était très connectée à la communauté élargie. Elle fut la seule infirmière, la seule femme et la seule francophone à siéger à la Commission royale d'enquête sur les services de santé. Peut-être en a-t-elle fait partie parce qu'Emmett Hall, qui dirigeait cette commission, avait été l'avocat des Sœurs Grises de la Saskatchewan. Tellement de choses étaient interreliées. Plus tard, elle est même devenue présidente du Conseil international des infirmières. Pouvez-vous nous parler un peu 
medicine was the way to go. They built in 1962 the building where our Faculty is still located, on Chemin Côte Ste Catherine in Montreal. They strategically built closer to Université de Montréal, a larger building, since they needed space for the new baccalaureate as entry to practice. They had to let go of the Institute, which they did in 1967. Its integration into the new Faculty of Nursing wasn't done very well, but they did let it go because they had the faculty. I say it was not done well because, during the Quiet Revolution in Québec, the separation between state and religion being a priority, laypeople would replace nuns as faculty despite their expertise. The Université de Montréal bought the Grey Nuns' building and their library and hired their teachers; it all became integrated in 1967, though the faculty had been in place since 1962 . The first program to open was the master's program.

Dr. Nelson: Who taught in that master's program? Where did Université de Montréal get the graduate faculty? Were they sisters as well?

Dr. Pepin: The Université de Montréal hired a few lay nurses who taught at the graduate level; they held master's degrees, from the United States mainly. One program option, nursing administration, opened in 1965 and the other option, nursing education, opened in 1966 under the direction of Julienne Provost, who was master's prepared.

Dr. Nelson: That was very early.

Dr. Pepin: They were all visionary women who really were committed to high standards of nursing education, and they didn't want to compromise. They wanted to be at the same quality level as other faculties. at Université de Montréal. The master's program helped establish nursing as a discipline. So it was through nursing research that the Faculty of Nursing, Université de Montréal, continued to develop and began to generate specific knowledge in nursing. Marie France Thibodeau and Louise Lévesque, in particular, applied for research grants and lobbied for specific support du nouveau campus? Ils ont donné son nom à la place publique, n'est-ce pas?

$D^{\text {re }}$ Pepin : Vous avez raison. La place publique du nouveau campus de l'Université de Montréal porte le nom d'Alice Girard, la première femme à porter le titre de doyenne. C'est merveilleux de célébrer son œuvre de pionnière en sciences infirmières, en administration de la santé et en administration universitaire. Le fait qu'elle soit parfaitement bilingue (elle est née au Connecticut dans une famille canadiennefrançaise) l'a aidée à participer à des discussions à travers le Canada et les ÉtatsUnis, ainsi qu'au niveau international.

J'ai rencontré Alice Girard dans les dernières années de sa vie. Elle aimait raconter une histoire en particulier. Elle était proche du doyen de la faculté de médecine, le $\mathrm{D}^{\mathrm{r}}$ Bonin, et ils avaient collaboré afin de soumettre une demande pour la création d'une faculté des sciences infirmières. Elle aimait à penser que certains représentants du corps professoral au sein du conseil ne savaient pas ce qui s'était passé; puisque les sciences infirmières n'étaient pas considérées comme une discipline scientifique, ils ont finalement remis la faculté en question, mais il était trop tard.

$\mathbf{D}^{\text {re }}$ Paul : Ce n'est pas une légende urbaine? J'ai aussi déjà entendu que les Sœurs Grises étaient bien déterminées à voir l'Institut transformé en faculté.

$D^{\text {re }}$ Pepin : Les Sœurs Grises avaient effectué des analyses comparatives au Canada et aux États-Unis pour savoir s'il était préférable de continuer en tant qu'école indépendante, de devenir une faculté ou de devenir une école au sein d'une faculté. Dans le dernier cas, il fallait également décider à quelle faculté l'école appartiendrait. Elles avaient conclu que la création d'une faculté totalement indépendante des autres entités, comme en médecine était la voie à suivre. En 1962, elles ont fait construire l'édifice sur le 
from the granting agencies for developing the discipline. Also through financially supporting young teachers to earn a $\mathrm{PhD}$ in universities outside of Montreal, the capacity for graduate education was being created. That was the years between the 1970s and 1993, the year when the doctorate program was inaugurated. MarieFrance Thibodeau was the dean from 1981 to 1993. She really supported the development of the Faculty by increasing significantly the number of $\mathrm{PhD}$ prepared members. First, the teachers were studying in other disciplines ( health sciences, education, psychology, epidemiology, etc.), but then the newer group of recruits, of which I am a part, had to study in nursing as it became a criteria for obtaining financial support. Many went to the United States--for example I went to Rochester, New York. This was a main factor to open a $\mathrm{PhD}$ program in nursing and to ensure that knowledge development would always continue to advance.

Dr. Paul: That's very interesting, Jacinthe, because that part is so similar to what happened in Alberta and it's the same era. If you look at Marie-France Thibodeau, she used to write with Shirley Stinson, from the University of Alberta, about preparing nurses at the $\mathrm{PhD}$ level. The same strategy was used in terms of sending people to school to do their $\mathrm{PhD}$.

Dr. Pepin: That was really important. We were very young coming back from our doctoral studies and already we were teaching master's degree courses. I remember sitting in Georgette Desjean's office, who was in charge of reviewing the project of creation of a doctorate program, and she was asking us what we thought. It was very much a series of developments, always moving. It was rare to find a stagnant moment.

Dr. Nelson: What sticks out to me in all this is what national leaders these women were in founding the faculty at the Universite de Montréal, and that's a great observation for us to make very clear in this special issue. I'm also chemin de la Côte-Sainte-Catherine, à Montréal, édifice qui abrite encore notre faculté à ce jour. La décision des Sœurs Grises de construire plus près de l'Université de Montréal était stratégique : ce bâtiment plus grand conviendrait à leur besoin d'espace pour le nouveau baccalauréat comme norme pour accéder à la pratique. Elles ont dû abandonner l'Institut en 1967 et son intégration dans la nouvelle Faculté ne s'est pas trop bien déroulée. Au moins, une faculté avait été créée. Je dis que ça ne s'est pas bien déroulé parce que pendant la Révolution tranquille au Québec, la séparation entre l'État et la religion était une priorité; les laïques remplaceraient les religieuses comme membres du corps professoral malgré leur expertise moins développée. L'Université de Montréal a fait l'achat de l'édifice des Sœurs Grises ainsi que de leur bibliothèque, en plus d'embaucher leurs enseignantes. Tout a été intégré en 1967, bien que la faculté était en place depuis 1962. Le premier programme à offrir des cours fut le programme de maîtrise.

$D^{\text {re }}$ Nelson : Qui enseignait dans ce programme? Où l'Université de Montréal est-elle allée chercher les membres du corps professoral? Étaient-elles aussi des religieuses?

$D^{\text {re }}$ Pepin : L'Université de Montréal a embauché quelques infirmières laïques pour enseigner au niveau postsecondaire; elles détenaient des diplômes de maitrise, principalement octroyés aux États-Unis. Une option du programme, l'administration des soins infirmiers, a été offerte pour la première fois en 1965 et l'autre, la formation en sciences infirmières, en 1966 sous la direction de Julienne Provost, qui détenait un diplôme de maîtrise.

$D^{\text {re }}$ Nelson : Ceci étaittrès tôt.

Dre Pepin : C'étaient toutes des femmes visionnaires vraiment engagées envers des normes élevées de formation en sciences 
curious about how they saw themselves internationally. Many of the faculty, including the sisters, were well known across borders. The Catholic Hospital Association of America was a very important force and a significant influencer in the Catholic hospital network in Canada. These women had access to that and mentorship from that, which we likely can't fully understand how good that was. I'm sure it was very important because they were very experienced sisters who were executives in huge hospitals and networks, and these women had that mentorship that your normal director of nursing in a non-religious hospital would not have had.

Dr. Paul: That's exactly it, Sioban. When you look at the history of hospital accreditation, the Catholic Hospital Association was the first to move to accreditation of hospitals, and it was in large part due to the sisters who had such high standards. In looking at the Grey Nuns, it was an author from Quebec, André Petitat, who compared them to a multi-national of health because they had established hospitals in the US and Brazil, and they were very efficient administrators.

Dr. Nelson: It is the same in Australia with the Catholic hospital system, but there wasn't the link to nursing education there. They weren't able to bring those standards and translate them into nursing education, unlike these women who were able to be ahead of a movement and exposed to advanced practices in American hospitals, which they were able to bring back to the universities. They pushed that in Canada in a way that made it quite different from any other country in the world.

Dr. Paul: There was a Grey Nun named Sister Létourneau in Alberta. When Cégeps were created in Quebec and colleges in Ontario for nursing education, Alberta was very slow on the uptake. However, she had been asked to write a report about the situation, and she recommended that all hospital programs be closed. The Grey Nuns had a hospital school in infirmières, et elles refusaient de faire des compromis. Elles voulaient offrir le même niveau de qualité que les autres facultés de l'Université de Montréal. Le programme de maîtrise a joué un rôle clé pour que les sciences infirmières deviennent une discipline. C'est donc grâce à la recherche en sciences infirmières que la Faculté des sciences infirmières de l'Université de Montréal a continué de se développer et a commencé à générer des connaissances particulières en soins infirmiers. MarieFrance Thibodeau et Louise Lévesque, entre autres, ont demandé des subventions de recherche et ont fait pression pour obtenir un soutien des organismes subventionnaires pour développer la discipline. Aussi, grâce au soutien financier offert aux jeunes enseignantes afin qu'elles obtiennent un doctorat dans des universités à l'extérieur de Montréal, il leur était à présent possible d'entreprendre des études supérieures. Tout ceci s'est produit entre les années 1970 et 1993, l'année de l'inauguration du programme de doctorat. Marie-France Thibodeau, qui a occupé la fonction de doyenne de 1981 à 1993, a vraiment soutenu le développement de la Faculté en augmentant considérablement le nombre de membres diplômées d'un programme de doctorat. $\mathrm{Au}$ début, les enseignantes provenaient d'autres disciplines (sciences de la santé, formation, psychologie, épidémiologie, etc.), mais le prochain groupe de recrues, dont je fais partie, devait étudier en sciences infirmières; c'était devenu un critère d'obtention d'aide financière. Beaucoup sont allées aux États-Unis; je suis moi-même allée à Rochester, dans l'état de New York. C'était un facteur essentiel pour établir et mettre en œuvre un programme de doctorat en sciences infirmières et assurer un avancement des connaissances.

$D^{\text {re }}$ Paul : C'est très intéressant, Jacinthe, parce que c'est si similaire à ce qui s'est passé en Alberta à la même époque. Marie- 
Edmonton, and when they closed it and went into partnership with was at the time McEwan College and Campus St. Jean, eventually the partnership dissolved because the University of Alberta said we can't have two faculties of nursing. This confirms the importance of education to the Grey Nuns.

Dr. Nelson: They really understood that the role of the university was to ensure that they were producing a workforce of nurses that had the capacity for leadership and to drive change.

Dr. Paul: There were lots of religious orders in Quebec, but I think the Grey Nuns were quite unique in their push for education. They were more proactive about it than other orders were.

Dr. Nelson: The Daughters of Charity were the same. The Daughters of Charity and the Sisters of Charity (in the US) were very committed to excellence in their hospitals and education, and in many places they were among the first nurses on the newly created nursing registers.

What do you think was the beginning of this international relationship for Université de Montréal, looking at leadership and education internationally?

Dr. Pepin: Nationally, the Grey Nuns were across Canada, helping to create that network. Also the Conference group of 11 schools that would become CASN, where Mother Allaire was present, was a starting moment, in terms of leadership in education. Representatives of the Université de Montréal were part of defining education standards with the rest of Canada, making sure that there was a Canadian vision. The Université de Montréal was always present at the $\mathrm{CASN}^{1}$ table at the Canadian Nurses Association (CNA) and the Canadian Nurses Foundation (CNF). For example at the first joint committee meeting among CNA, CASN, and CNF (funded by the Kellogg Foundation) held in 1978 to study the potential creation of a doctoral program in nursing, the Université de
France Thibodeau écrivait avec Shirley Stinson, de la University of Alberta, sur la préparation des infirmières au niveau du doctorat. La même stratégie a été utilisée pour envoyer des étudiantes faire leur doctorat.

$D^{\text {re }}$ Pepin : C'était vraiment important. Nous étions très jeunes quand nous terminions nos études doctorales, et déjà nous donnions des cours au niveau de la maîtrise. Je me souviens, j'étais assise dans le bureau de Georgette Desjean, qui était chargée de revoir le projet de création d'un programme de doctorat, et elle nous demandait ce que nous en pensions. C'était vraiment une série de développements, toujours en mouvement. Les moments où les choses ne changeaient pas se faisaient rares.

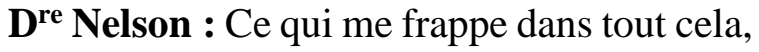
c'est à quel point ces femmes ont fait figure de chefs de file nationales en fondant la Faculté des sciences infirmières de l'Université de Montréal. C'est une belle observation que nous devons faire ressortir très clairement dans ce numéro spécial. Je suis également curieuse de savoir comment elles se percevaient au niveau international. Bon nombre du corps enseignant (y compris les religieuses) étaient connus à l'extérieur du pays. La Catholic Hospital Association of America (association américaine des hôpitaux catholiques) était une force essentielle et une influence importante dans le réseau des hôpitaux catholiques au Canada. Ces femmes y ont eu accès ainsi qu'au mentorat qu'elle offrait; c'était une bonne chose, au-delà de ce que nous pouvons penser aujourd'hui. Je suis sûre que c'était très important parce que des religieuses expérimentées étaient cadres dans d'immenses hôpitaux et réseaux, et elles avaient accès à un mentorat auquel une

\footnotetext{
${ }^{1}$ The current name of the Canadian Association of Schools of Nursing (CASN) is used here to facilitate reading.
} 
Montréal/McGill duo was supported by CASN because it was in Montreal that you could find the most faculty members prepared at the doctoral level, active in research. Its dynamism continued through CASN, but also through other organizations.

Internationally, the Université de Montréal was first involved with developing countries. Later, at the intersection of two worlds (defining the nursing discipline mainly with the English speaking world and theorizing the education mainly with the French speaking world) and collaborating across Canada and internationally, the Faculty of Nursing at the Université de Montréal developed an expertise in innovation in nursing education. Nursing education at the graduate and undergraduate level in French-speaking countries in Europe and Africa was propelled by the Bologna Process on Higher Education. It confirmed the reciprocity between European countries to have a general requirement for nursing, and among other professions like engineering. European and African countries looked at what was done in nursing in Canada. There were interested in learning what is the discipline of nursing and how to develop nursing research programs. We worked with Switzerland for example in the 1990s, and now the SIDIIEF (Secrétariat international des infirmières et infirmiers de l'espace francophone), a 20 years old organization that groups the French-speaking countries, created a nursing education council to promote developing quality standards. The SIDIIEF adopted a position statement in 2012 supporting university-education for all new nurses. Many Francophone countries are moving in that direction, catching up, at diverse pace.

Dr. Paul: To summarize a bit, you're saying that the strength of the university in terms of nursing education, is partly that it was connected to the English world, while the other Francophone countries weren't as much, so they directrice des soins infirmiers dans un hôpital non religieux n'aurait pas eu accès.

D re Paul : C'est bien ça, Sioban. La Catholic Hospital Association a été la première organisation à adopter l'agrément des hôpitaux, et c'était en grande partie grâce auxreligieuses, qui avaient des normes très élevées. Un auteur québécois, André Petitat, a comparé les Sœurs Grises à une multinationale de la santé parce qu'elles avaient fondées des hôpitaux aux États-Unis et au Brésil, et qu'elles étaient des administratrices très efficaces.

$D^{\text {re }}$ Nelson : Il y avait un scénario similaire en Australie, avec un système hospitalier « catholique », mais non lié à la formation en sciences infirmières. Le système n'a pas été en mesure de prendre ces normes et de les traduire en formation en sciences infirmières, contrairement à ces femmes qui ont su être en avance sur un mouvement et qui ont été exposées aux pratiques avancées dans les hôpitaux américains, pratiques qu'elles ont par la suite pu présenter dans les universités. Elles ont imposé ces pratiques au Canada d'une manière qui le distinguait manifestement de tout autre pays du monde.

$D^{\text {re }}$ Paul : Sœur Létourneau, une Sœur Grises qui était en Alberta dans les années 60 démontre en un sens comment les idées voyageaient. Lorsque les cégeps ont été créés au Québec et les collèges en Ontario pour la formation en sciences infirmières, l'Alberta a été très lente à suivre le mouvement. Cependant, on a demandé à Sœur Létourneau de rédiger un rapport sur la situation, et elle a recommandé que tous les programmes hospitaliers soient fermés. Les Sœurs Grises avaient une école en milieu hospitalier à Edmonton. Elles l'ont fermée et ont créé un partenariat avec la MacEwan University (MacEwan College à l'époque) et le Campus Saint-Jean, mais celui-ci s'est finalement dissous parce que la University of Alberta a décrété qu'il était impossible d'avoir deux 
developed more slowly in bringing nursing education to universities.

Dr. Pepin: That's only part of the story. The other part is related to the leadership of the visionary nurses, first the Grey nuns and then the lay faculty. The second French-speaking university to create a faculty of nursing was l'Université St-Joseph au Liban, a Catholic university in Lebanon.

Dr. Nelson: Another way to think about this, or to say the same thing in a slightly different way, is that a couple of elements were in place. One is that the Grey Nuns had a national Canadian network, so they were very much part of the national nursing community, just in a way that was different from other groups of sisters. The advancement of undergraduate and graduate nursing education was, without question, a very North American movement. And the Grey Nuns were full members and leaders of that movement.

Lebanon is an interesting case, too. The American university in Lebanon had a very important nursing faculty as well. Lebanon is another place, unlike others in the world, that had a strong American influence in the nursing profession, and perhaps that was also relevant to the advancement of the faculty in the Francophone community in Lebanon as well.

It's clear that any attempt to bring nursing education to the university was an abortive attempt almost everywhere else around the world until the latter part of the $20^{\text {th }}$ century. North America was distinctive in this. Countries where you $d o$ find the odd program were overwhelmingly founded on Rockefeller Foundation money and were part of American initiatives to support medical development and hospital reform. They would bankroll a nursing program at the same time. These programs are anomalies - they're not really part of the country's movement. They're a unique event, facultés des sciences infirmières. Cela confirme l'importance de la formation pour les Sœurs Grises.

$D^{\text {re }}$ Nelson : Elles comprenaient vraiment que le rôle de l'université était d'assurer un effectif d'infirmières capables de diriger et de provoquer le changement.

$D^{\text {re }}$ Paul : Le Québec comptait de nombreux ordres religieux, mais l'attention que les Sœurs Grises portaient à l'éducation était plutôt unique. Elles étaient, en effet, plus proactives à cet égard que bien d'autres ordres.

$D^{\text {re }}$ Nelson : Les Filles de la Charité de Saint-Vincent-de-Paul avaient une approche similaire. Elles étaient, comme les Sisters of Charity aux États-Unis, dédiées à l'excellence au niveau de l'éducation et des services prodigués dans leurs hôpitaux. Dans de nombreux endroits, elles figuraient parmi les premières infirmières inscrites aux nouveaux registres infirmiers.

Selon vous, quand cette relation internationale a-t-elle commencé pour l'Université de Montréal, particulièrement en regard du leadership et de la formation à l'international?

$D^{\text {re }}$ Pepin : Les Sœurs Grises étaient présentes dans l'ensemble du Canada, où elles contribuaient à la création de ce réseau. Aussi, le groupe de 11 écoles du colloque qui deviendrait 1'ACESI, auquel Mère Allaire appartenait, a été décisif en matière de leadership dans la formation. Des représentantes de l'Université de Montréal ont participé, avec des représentants d'ailleurs au Canada, à la définition des normes de formation, s'assurant qu'une vision canadienne y soit reflétée. L'Université de Montréal a toujours été active au sein de l'ACESI ${ }^{2}$ ainsi qu'auprès de l'Association des infirmières et infirmiers du

${ }^{2}$ Le nom actuel de l'Association canadienne des écoles de sciences infirmières (ACESI) est utilisé ici afin de faciliter la lecture. 
whereas the Université de Montréal wasn’t a unique event. They were a Canadian leader.

Dr. Paul: I was an undergraduate student there at the Université de Montréal in the late 1970s, and I remember Georgette Desjean introducing us to some of the master's students who were from Africa.

Dr. Nelson: They may also have been supported by Rockefeller Foundation money. The University of Toronto had a lot of international students on Rockefeller Foundation fellowships. The Foundation was involved in African Francophone countries in the development of public health and all sorts of things.

Dr. Pepin: And as you say, the Université de Montréal was a leader in the development of the discipline of nursing and in the direction of nursing research. It wasn't repeating but rather participating and being together in this movement for the development of nursing knowledge.

Dr. Paul: That's interesting too. One of the faculty members, Evelyn Adam, developed a nursing model during that era.

Dr. Pepin: Evelyn was telling her students "you can be inspired by any nursing conceptual framework, but you must be aware that you have a conception, whether it is formalized or not". The philosophical/ theoretical/ conceptual nursing underpinnings were always really important in our programs. I must admit that $L a$ pensée infirmière, first published in 1994 with Suzanne Kérouac as first author was also a significant contribution to the francophone nursing education programs; to learn about what we think as nurses and how we incorporate a nursing perspective in practice, research, and teaching. Now in its $4^{\text {th }}$ edition, the content is richer, and thicker, participating in the movement of change in our discipline, which is a characteristic of our Faculty...

Dr. Paul: There's one other thing we would like to discuss. Quebec, in my view, is a leader in
Canada (AIIC) et de la Fondation des infirmières et infirmiers du Canada (FIIC). Par exemple, lors du premier comité paritaire de l'AIIC, de l'ACESI et de la FIIC (financé par la Fondation Kellogg) tenu en 1978 pour étudier la création potentielle d'un programme de doctorat en sciences infirmières, le duo Université de Montréal/McGill a été soutenu par l'ACESI, car c'est à Montréal que l'on pouvait trouver le plus grand nombre de professeures préparées au niveau du doctorat et actives en recherche. Le dynamisme du duo s'est propagé à travers l'ACESI, mais aussi à travers d'autres organisations.

À l'international, l'Université de Montréal s'est d'abord impliquée auprès des pays en développement. Plus tard, à l'intersection de deux mondes (la définition de la discipline infirmière principalement avec les pays anglophones et la théorie de la formation principalement avec la francophonie) et avec une collaboration à travers le Canada et à l'international, la Faculté des sciences infirmières de l'Université de Montréal a développé une expertise en matière d'innovation au sein de la formation en sciences infirmières. La formation en sciences infirmières au premier cycle et aux cycles supérieurs dans les pays francophones d'Europe et d'Afrique a été propulsée par le processus de Bologne sur l'enseignement supérieur. Ce processus a confirmé le besoin d'une certaine réciprocité entre les pays européens désirant des exigences générales pour les sciences infirmières, ainsi que pour d'autres professions comme l'ingénierie. Les pays d'Europe et d'Afrique surveillaient ce qui se faisait en sciences infirmières au Canada. Ils voulaient comprendre ce qu'était cette discipline des sciences infirmières et apprendre comment mettre sur pied des programmes de recherche dans le domaine. Nous avons travaillé avec la Suisse dans les années 1990, et maintenant le SIDIIEF (Secrétariat international des infirmières et 
international nursing in French, yet it still doesn't have the baccalaureate entry-to-practice requirement. We would like your thoughts on that, and perhaps also your thoughts on the marrying together of DECs with a science diploma and DECs with a nursing diploma.

Dr. Pepin: This is an interesting and complex story. There is a remarkable success in graduate education, for example with the Nurse Practitioners program at the master's level, yet the baccalaureate is still not the requirement for entry-to-practice in Quebec. Of course, there are many factors involved, and I will just bring up a few here. Inside the profession, I would say that there hasn't been, in the last few years, enough dialogue to understand the different points of view within the nursing leadership, to raise problems and identify solutions. Is there enough concertation, are we discussing and working in one direction? We still have to learn from other provinces.

However, in this discussion, there has been a lot of interference from non-nurses. It was through the Quiet Revolution in the 1960s, which brought a major reform in education in Québec, and following the report from the Parent Commission (1966), that Ministry of education and the Cégeps (collèges d'enseignement général et professionnel) were created in 1967. The intent was to democratise and widen the access to education. As far as nursing education is concerned, it was proposed to the Order of nurses in Québec (ONQ) that there would be one three-years professional nursing program developed at the Ministry of education level to create uniformity in what would be taught in Cégeps. At the time, nursing education programs in hospitals were criticized for being too different and of uneven quality. This uniformity while maintaining accessibility to nursing education was promised and the ONQ was to provide to the Ministry information on the nature of nursing. University nursing education, that followed a two-years general science program in Cégeps, was viewed at the time as elitist and knowledge-oriented while not infirmiers de l'espace francophone), organisation regroupant les pays francophones fondée il y a 20 ans, a créé un conseil consultatif sur la formation infirmière pour favoriser le développement de normes en matière de qualité. Le SIDIIEF a adopté une prise de position en 2012 en faveur de la formation universitaire pour toutes les nouvelles infirmières. De nombreux pays francophones avancent maintenant dans cette direction à des rythmes divers, rattrapant leur retard.

Dre Paul : Donc, la connexion de l'Université au monde anglophone pour la formation en sciences infirmières représente une partie de sa force. Puisque les autres pays francophones n'avaient pas de tels liens, la formation en sciences infirmières dans leurs universités s'y est développée plus lentement.

$D^{\text {re }}$ Pepin : Ce n'est qu'un volet de l'histoire. L'autre volet implique le leadership d'infirmières visionnaires, les Sœurs Grises et par la suite, les membres laïques du corps professoral. La deuxième université francophone à développer une faculté des sciences infirmières a été l'Université SaintJoseph, à Beyrouth, un établissement catholique du Liban.

$D^{\text {re }}$ Nelson : Bref, quelques éléments étaient en place. Entre autres, les Sœurs Grises avaient un réseau national canadien, et faisaient par ce fait même vraiment partie de la communauté infirmière nationale, simplement d'une manière différente des autres congrégations de sœurs. L'avancement de la formation en sciences infirmières au premier cycle et aux cycles supérieurs était sans aucun doute un mouvement très nord-américain, dont les Sœurs Grises étaient membres à part entière et chefs de file.

Le cas du Liban est également fascinant. L'université américaine au Liban avait une faculté des sciences infirmières très 
practical enough; interestingly, numerous nursing hospital programs were affiliated to a university prior to the existence of Cégeps. This was supposed to be a pilot project, but many years later the program is still in place. Hence, many non-nurses invite themselves into the debate on nursing education. In that sense the ONQ at the time gave up a crucial decision regarding the required education for practicing nursing. Any change to the program is done through the ministry in contrast to university education which has flexibility in adapting to health needs. Successive ONQ presidents held different views on this issue. For example, in the 1980s, with the rest of Canada, Jeannine Pelland supported the position of baccalaureate as the entry-to-practice requirement in the year 2000.

A step in that direction, in 2000, was the beginning of the work in consortia of Cégeps and universities to create integrated nursing programs (DEC-BAC). And in the last 20 years, we've had everything in place for the decision of baccalaureate as the entry to practice requirement; the integrated DEC-BAC program $(3+2$ years) is equivalent to the direct entry BAC program $(2+3$ years). What is left to do is to close the entry to nursing practice at the end of the 3 years DEC level while continuing as it is, with two ways of entering to nursing education: directly to the university $(2+3)$ or through the Cégep first $(3+2)$. The decision, however, is both outside and inside nursing at the moment. The Federation of Cégeps remains a strong opposing force. The unions have a role to play in assuring that the actual nurses who do not have a baccalaureate will not lose out with the shift. It needs to be thought through carefully with all the stakeholders, taking into account the current socioeconomic context. At the moment the baccalaureate as entry to practice is the first of the six strategic orientations of the ONQ. Throughout all these years, there has been a constant battle, and I believe Quebec has now some winning conditions. importante. Contrairement à d'autres endroits dans le monde, la profession infirmière a connu une forte influence américaine au Liban. Peut-être cette influence a-t-elle également contribué à l'avancement de la faculté dans la communauté francophone libanaise.

Il est évident que toute tentative d'introduire la formation en sciences infirmières dans le milieu universitaire était avortée presque partout ailleurs dans le monde jusqu'à la fin $\mathrm{du} \mathrm{XX}^{\mathrm{e}}$ siècle. L'Amérique du Nord se distinguait à cet égard. Dans les pays offrant un programme, ceux-ci étaient massivement financés par la Fondation Rockefeller et faisaient partie des initiatives américaines visant à soutenir le développement médical et la réforme hospitalière. La Fondation, d'ailleurs, finançait un programme de sciences infirmières du même coup. Ces programmes sont toutefois des anomalies; ils ne font pas vraiment partie du mouvement des pays en question. Ils représentent un événement unique, ce qui n'était pas le cas pour l'Université de Montréal, qui était plutôt une chef de fille canadienne.

$D^{\text {re }}$ Paul : J'étais étudiante de premier cycle à l'Université de Montréal à la fin des années 1970, et je me souviens que Georgette Desjean nous a présenté certaines étudiantes à la maîtrise qui venaient d'Afrique.

$D^{\text {re }}$ Nelson : Elles étaient peut-être également financées par la Fondation Rockefeller. La University of Toronto comptait de nombreuses étudiantes internationales qui profitaient des bourses de cette Fondation, qui s'impliquait dans le développement de la santé publique et autres initiatives au sein des pays africains francophones.

Dre Pepin : Comme vous le dites, l'Université de Montréal a été une chef de file dans le développement des sciences infirmières et dans la direction de la 
Dr. Paul: The fact that these Cégeps were all united together was another key factor. We had the same battles, like making sure that it's the same for every nurse. In our case, it was even more complicated because we had hospital schools, colleges, and universities. And you're saying that they Cégeps were created from the Quiet Revolution. It's interesting as well that Ontario schools moved to colleges at that same time, and that was in part the result of $\mathrm{e}$ Spotlight on Nursing Education that had been published by Helen Mussallem in the context of the Royal Commission on Health Services, where she was saying that nursing education needed to leave hospitals.

Dr. Pepin: We might have to emphasize that studying at the university level does not mean that you can't focus on nursing practice. Many still think that university education is out of touch with practice, which is far from the reality. Nursing programs have integrated simulation and included clinical placement in the first year for at least 15 years.

Dr. Nelson: It's a powerful trope that is a useful point to argue for the maintenance of the status quo. There are vested interests in maintaining the higher education structure that is, as you say, outside of nursing's hands. And they can easily use an essentially 100-year-old critique that the university educated nurse is not practice focused or too theoretical to simply resist change, despite the lack of any supportive evidence. It's a very political thing to say rather than a rational one. I also think that the rest of the country, especially Ontario and $\mathrm{BC}$, has the practical nurse role, which is a two-year prepared role. In Ontario, you've got those who argue there's no difference between a registered nurse and a practical nurse (PN). We now see the re-emergence of the old myth of baccalaureate nurses being over educated for nursing jobs, and the two-year prepared nurses are more practical and cheaper.

Dr. Paul: In preparing the questions, we had talked about the practical nurse role in the rest recherche dans le domaine. Elle nous encourageait à participer au mouvement de développement des connaissances infirmières.

$D^{\text {re }}$ Paul : C'est aussi intéressant. L'une des membres du corps professoral, Evelyn Adam, avait développé un modèle de soins infirmiers à l'époque.

$D^{\text {re }}$ Pepin : Evelyn disait à ses étudiantes : «Vous pouvez vous inspirer de n'importe quel cadre conceptuel infirmier, mais vous devez être conscientes que vous avez une conception, que celle-ci soit formalisée ou non. » Les fondements philosophiques, théoriques et conceptuels des sciences infirmières ont toujours eu une grande importance dans nos programmes. Je dois admettre que le livre La pensée infirmière, publié pour la première fois en 1994 et dont Suzanne Kérouac était l'auteure principale, a également contribué de façon significative aux programmes francophones de formation en sciences infirmières. Ce texte nous a poussées à apprendre ce que nous pensons en tant qu'infirmières et à découvrir comment nous intégrons une perspective infirmière dans la pratique, la recherche et l'enseignement. Maintenant dans sa $4^{\mathrm{e}}$ édition, son contenu est plus riche et plus complet, contribuant à la vague de changements dans notre discipline, caractéristique de notre Faculté.

$D^{\text {re }}$ Paul : Nous aimerions discuter d'un autre sujet. Je suis d'avis que le Québec est en tête de peloton en ce qui concerne les soins infirmiers en français à l'échelle de la planète. Et pourtant, la province n'a toujours pas d'exigences en lien avec l'accès à la pratique au niveau dude baccalauréat. Nous aimerions vous entendre à ce sujet, et peutêtre pourriez-vous aussi partager vos réflexions sur le DEC en sciences et le DEC comme diplôme professionnel en soins infirmiers. 
of the country, and how Quebec has the infirmière auxiliare (AI). What has happened in the rest of Canada is that the PN programs have become 2-year programs that are clones of the old RN diploma programs, but with enhancements.

Dr. Nelson: In Ontario, the scope of practice is the same. There's no difference from a registration point of view. It's meant to be a subtle management decision as opposed to a regulatory decision as to who looks after which patient.

Dr. Pepin: Quebec could be in danger of going in that direction at some point. Some hospitals, mainly university hospitals, made the decision in the 2000s, not to hire PNs (IAs in Quebec), and requested more educated care attendants (préposés aux bénéficiaires), though eventually they hired them back. If we were to situate IA's education at the Cégep-level, the question of baccalaureate nurses being over educated could resurface. By my way of thinking, the Grey Nuns as heads of hospitals would structure the work to maximize the different strengths in nursing. At the moment, nurses' expertise is very poorly used. Nurses need to get more involved, in making the decisions for nursing in order to improve nursing care and teamwork for the benefits of patients and organizations.

Dr. Paul: That's a very important point, and it's important across the country. We went from a world where the sisters were in charge to a world where there were directors of nursing in hospitals to a world where nursing leadership is not as clearly articulated.

Dr. Nelson: Though you may have a special program at a hospital that might be run by nurses, it's more often that nurses are being managed by non-nurses. And this has really come up around Covid, where you having nurses deployed in ways that don't use the nursing resources effectively. Because the people making nursing decisions don't have the knowledge about nursing they need to optimize what nurses have offer. The registered nurse is
$D^{\text {re }}$ Pepin : Voilà une affaire intéressante, mais complexe. L'enseignement aux cycles supérieurs connaît un succès remarquable, par exemple avec le programme de formation des infirmières praticiennes au niveau de la maîtrise, mais le programme de baccalauréat n'est toujours pas exigé pour accéder à la pratique au Québec. Je vais aborder quelques-uns des nombreux facteurs qui entrent en ligne de compte. Je dirais qu'au cours des dernières années on n'a pas assez cherché à comprendre les différents points de vue exprimés par les leaders en sciences infirmières, à soulever des problèmes et à trouver des solutions. Y a-t-il suffisamment de concertation, et nos discussions et nos efforts sont-ils harmonisés? Nous pourrions en apprendre davantage des autres provinces canadiennes.

Cependant, cette discussion a engendré beaucoup d'interférence de la part de personnes qui ne sont pas infirmiers ou infirmières. C'est en 1967, à la suite de la Révolution tranquille des années 1960 (qui a amené une réforme majeure de l'éducation au Québec) et du rapport de la Commission Parent (1966), que le ministère de l'Éducation et les cégeps (collèges d'enseignement général et professionnel) ont été créés. L'objectif était de démocratiser et d'améliorer l'accès à l'éducation. Un programme professionnel de trois ans en sciences infirmières développé par le ministère de l'Éducation a été proposé à l'Ordre des infirmières et infirmiers du Québec (OIIQ) pour uniformiser ce qui serait enseigné dans les cégeps. À l'époque, les programmes de formation en sciences infirmières dans les hôpitaux étaient critiqués; on disait qu'ils étaient trop différents et de qualité inégale. On avait promis une uniformité et un maintien de l'accessibilité à la formation en sciences infirmières, et l'OIIQ devait fournir au ministère des informations sur la nature des sciences infirmières. La formation 
just one voice around the director or president's table, and they don't actually have authority over the patient care or even the work of nurses. It's an extraordinary contrast to the sisters' hospitals.

Dr. Pepin: Our last reforms have been detrimental to the nursing structure, which fell apart in some milieus during the Covid pandemic. Not to idealize the past, because there were always thinks that were not working, despite the best efforts.

Dr. Nelson: It's not to be critical of those working very hard right now, but the structure doesn't enable them to work effectively.

Dr. Pepin: Yes, the structure needs to be rethought.

Dr. Paul: What do you think is the most interesting development in nursing education history in your career so far?

Dr. Pepin: This is an interesting and difficult question. What comes to mind most is the transition from an almost exclusively sciencebased education with discipline-separated courses (statistics, pharmacology, nursing, etc.) and even though there were clinical placements, the students were left to combine this knowledge all together to be able to practice. The transition went to situation-based or learning-centred education with more focus on active learning, which is important to support the development of nursing competencies such as clinical reasoning. This is an interesting change, though it is not unique to nursing as it is the same in education for other health care professions. Why I find it so interesting is that, in looking ahead, I think we need to make another shift. We need to continue thinking about experiential nursing education, but we need to move toward a transformative way of teaching. This would mean looking more deeply into what a nurse could be. We talked about change agents, and when I studied in the 1970s, we were told that we were going to be change agents - I believe this became true - we are here universitaire en sciences infirmières, qui faisait suite à un programme de sciences générales de deux ans dans les cégeps, était considérée à l'époque comme étant élitiste et axée sur le savoir plutôt que sur la pratique. Fait intéressant, de nombreux programmes hospitaliers en sciences infirmières étaient affiliés à une université avant que les cégeps soient créés. C'était censé être un projet pilote, mais plusieurs années plus tard, le programme est toujours en place. Par conséquent, de nombreuses personnes qui ne sont pas du domaine infirmier s'invitent dans le débat sur la formation en sciences infirmières. En ce sens, l'OIIQ a alors renoncé à l'époque à prendre une décision cruciale concernant la formation requise pour la pratique des soins infirmiers. Tout changement au programme devait se faire par l'intermédiaire du ministère contrairement à la formation universitaire, qui, munie d'une certaine flexibilité, pouvait s'adapter aux besoins en matière de santé. Les présidentes successives de l'OIIQ ont eu différentes opinions sur cette question. Par exemple, dans les années 1980, Jeannine Pelland, comme bien d'autres intéressées de partout au pays, a soutenu la position du baccalauréat comme exigence pour accéder à la profession.

En 2000, un pas important dans cette direction fut le début de la collaboration des cégeps et des universités dans le but de créer des programmes intégrés de sciences infirmières (DEC-BAC). Au cours des 20 dernières années, nous avons tout mis en place pour que le baccalauréat devienne une exigence pour accéder à la pratique; le programme intégré DEC-BAC $(3+2$ ans $)$ équivaut au programme de baccalauréat à entrée directe $(2+3$ ans $)$. Il ne reste plus qu'à exclure l'accès à la pratique infirmière à la fin du DEC de 3 ans et de poursuivre avec seulement deux façons d'accéder à la formation infirmière : directement à l'université $(2+3)$ ou en passant d'abord par 
talking together after all. I think that we need to guide students to become, as Benner said, nurses who have the authority to practice nursing and not just the responsibility. We need to work on nursing identity and culture. We've focused a lot on the competencies, now we need to work toward this third transition of what is nursing education.

Dr. Nelson: That's wonderful. What a thoughtful conclusion. Thank you.

Cohen, Y., Pepin, J., Lamontagne, E., \& Duquette, A. (2002) Les sciences infirmières - genèse d'une discipline. Les presses de l'université de Montréal.

Sœur Denise Lefebvre. (n.d.). Ville de Montreal.

https://ville.montreal.qc.ca/ordre/en/soe ur-denise-lefebvre

Ville de Montréal (2019). La Ville de Montréal nomme la place centrale du projet MIL Montréal en l'honneur de Mme Alice Girard. http://ville.montreal.qc.ca/portal/page? pageid $=5798,42657625 \& \_$dad $=$portal $\&$ _schema $=$ PORTAL\&id $=31987$ le cégep $(3+2)$. La décision, cependant, dépend à la fois des sciences infirmières et de facteurs externes. La Fédération des cégeps s'y oppose toujours fermement. Les syndicats, quant à eux, s'impliquent afin d'assurer que les infirmières qui ne détiennent pas de baccalauréat ne perdront pas au change. La décision doit être mûrement réfléchie avec tous les intervenants et en tenant compte du contexte socio-économique. À l'heure actuelle, le baccalauréat comme exigence pour accéder à la pratique est la première des six orientations stratégiques de l'OIIQ. Une lutte constante sévit depuis toutes ces années, et je crois que le Québec a maintenant des conditions gagnantes.

$D^{\text {re }}$ Paul : Les actions unifiées de ces cégeps constituaient un autre facteur clé. Nos défis étaient les mêmes, par exemple, celui de s'assurer que toutes les infirmières soient traitées de la même façon. Dans notre cas, la situation était plus compliquée compte tenu de l'existence d'écoles en milieu hospitalier, de collèges et d'universités. Vous dites que les cégeps ont été créés à la suite de la Révolution tranquille. Il est également intéressant de noter que les écoles de l'Ontario ont déménagé dans les collèges à la même époque, en partie à cause du rapport Spotlight on Nursing Education, publié par Helen Mussallem dans le contexte de la Commission royale d'enquête sur les services de santé, qui notait que la formation en sciences infirmières devait se faire ailleurs que dans les hôpitaux.

$D^{\text {re }}$ Pepin : Il est important de souligner que les études universitaires ne font pas en sorte que les étudiantes sont privées de la possibilité de se concentrer sur la pratique infirmière. Bien des personnes pensent toujours que le milieu universitaire est loin de la pratique, mais ce n'est pas le cas. Depuis plus de 15 ans, les programmes de sciences infirmières comprennent des stages 
en milieu clinique dès la première année et des activités de simulation.

$D^{\text {re }}$ Nelson : C'est un trope puissant et utile pour plaider le maintien du statu quo. Certains intérêts particuliers tiennent à maintenir la structure de la formation de niveau supérieur, comme vous le dites, hors de portée des infirmières. On peut facilement utiliser un argument pratiquement centenaire selon lequel l'infirmière diplômée à l'université n'est pas axée sur la pratique ou se concentre trop sur la théorie, malgré l'absence de données probantes, simplement pour résister au changement. L'argument est plus politique que logique. Je pense également que le reste du pays, en particulier l'Ontario et la Colombie-Britannique, offre le rôle d'infirmière auxiliaire, qui requiert deux ans de préparation. En Ontario, certains soutiennent qu'il n'y a pas de différence entre une infirmière autorisée et une infirmière auxiliaire. Nous voyons maintenant la réémergence du vieux mythe selon lequel les infirmières formées au baccalauréat sont surqualifiées pour les emplois en soins infirmiers, et que les infirmières qui ont une préparation de deux ans sont plus axées sur la pratique et coûtent moins cher.

$\mathbf{D}^{\text {re }}$ Paul : En préparant les questions, nous avons parlé du rôle d'infirmière auxiliaire dans le reste du pays et de la façon dont le Québec offre également cerôle. Dans le reste du Canada, les programmes de formation des infirmières auxiliaires sont devenus des programmes de deux ans qui sont des clones des anciens programmes menant à un diplôme d'infirmière autorisée, auquel on a apporté des améliorations.

$D^{\text {re }}$ Nelson : La portée de la pratique est la même en Ontario, avec aucune distinction au niveau de l'inscription. La question de qui s'occupe de tel patient est laissée à la subtile discrétion des intervenantes, plutôt que d'être légiférée. 
$D^{\text {re }}$ Pepin : Le Québec pourrait se retrouver sur cette voie à un moment donné. Dans les années 2000, certains hôpitaux, principalement des hôpitaux universitaires, ont décidé de ne plus embaucher d'infirmières auxiliaires et de les remplacer par davantage de préposés aux bénéficiaires plus scolarisés, avant de finalement revenir sur leur décision et les réembaucher. Si l'on devait établir la formation des infirmières auxiliaires au niveau du cégep, la question de la surformation des infirmières au baccalauréat pourrait ressurgir. À mon avis, les Sœurs Grises, en tant que directrices d'hôpitaux, organisaient les activités de manière à maximiser les différentes forces en sciences infirmières. En ce moment, l'expertise des infirmières est très mal utilisée. Elles doivent s'impliquer davantage dans la prise de décisions en matière de soins infirmiers afin d'améliorer ces derniers et de privilégier le travail d'équipe au profit des patients et des organisations.

$D^{\text {re }}$ Paul : Ce point est critique, et ce à l'échelle du pays. Nous sommes passées d'un monde où les religieuses $s$ étaient aux commandes à un monde où il y avait des directrices des soins infirmiers dans les hôpitaux, puis au monde d'aujourd'hui, où le leadership infirmier n'est pas aussi clairementvisible dans les structures hospitalières.

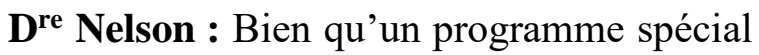
géré par des infirmières peut être offert dans un hôpital, il est plus probable que les infirmières soient gérées par des membres du personnel provenant d'autres domaines. Un phénomène est apparu avec la COVID, où des infirmières sont déployées de manière telle que les ressources infirmières sont utilisées inefficacement, parce que les personnes qui prennent des décisions en matière de soins infirmiers ne détiennent pas les connaissances nécessaires pour optimiser leurs services. L'infirmière autorisée n'est qu'une voix parmi d'autres à la table de 
direction, et celle-ci n'a aucun pouvoir sur les soins prodigués aux patients ni même sur son travail et celui de ses consœurs. C'est un contraste extraordinaire avec les hôpitaux des religieuses. .

$\mathbf{D}^{\text {re }}$ Pepin : Nos dernières réformes ont été préjudiciables à l'organisation des soins infirmiers, qui s'est effondrée dans certains milieux pendant la pandémie de COVID. Cependant, je ne veux pas idéaliser le passé, car ça ne fonctionnait pas toujours comme sur des roulettes, en dépit des efforts déployés.

$D^{\text {re }}$ Nelson : Il ne faut pas critiquer celles qui travaillent très dur actuellement, car la structure ne leur permet pas de travailler efficacement.

$D^{\text {re }}$ Pepin : Effectivement, la structure devra être attentivement examinée.

$D^{\text {re }}$ Paul : Selon vous, quel est le développement le plus intéressant de l'histoire de la formation en sciences infirmières dans votre carrière jusqu'à présent?

$D^{\text {re }}$ Pepin : Voilà une question intéressante, mais pas facile. Ce qui me vient d'abord à l'esprit, c'est qu'au départ, la formation était presque exclusivement scientifique avec des cours séparés par discipline (statistiques, pharmacologie, soins infirmiers, etc.). Même si l'on offrait des stages en milieu clinique, les étudiantes devaient combiner des connaissances diverses pour être capables de pratiquer. Il y a ensuite eu une transition vers une formation basée sur la situation ou centrée sur l'apprentissage avec un accent plus pointu sur l'apprentissage actif, essentiel au développement des compétences infirmières telles que le raisonnement clinique. Il s'agit d'un changement intéressant, bien qu'il ne soit pas propre aux sciences infirmières; la formation des autres professions de la santé a évolué de façon similaire. Je trouve cette transition 
particulièrement intéressante, car je pense que nous devrons faire un autre virage à l'avenir. Nous devons continuer à réfléchir à la formation des sciences infirmières par l'expérience tout en nous dirigeant vers une méthode d'enseignement transformatrice. On devrait donc examiner plus en profondeur ce que pourrait être une infirmière. Nous avons parlé d'agentes de changement, et quand j'ai étudié dans les années 1970, on nous a dit que nous allions être de telles agentes. Je crois que cela s'est avéré; nous sommes ici en train de discuter, après tout. Je pense que nous devons guider les étudiantes pour qu'elles deviennent, comme Benner l'a dit, des infirmières qui ont le pouvoir, et non seulement la responsabilité, de pratiquer les soins infirmiers. Nous devons travailler sur l'identité et la culture infirmières. Nous nous sommes beaucoup concentrées sur les compétences, nous devons maintenant travailler à cette troisième transition afin de déterminer la nature de la formation en sciences infirmières.

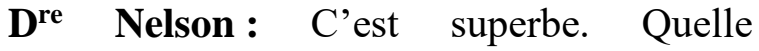
conclusion judicieuse. Merci!

Cohen, Y., Pepin, J., Lamontagne, E. et Duquette, A. (2002) Les sciences infirmières - genèse d'une discipline. Les Presses de l’Université de Montréal.

Sœur Denise Lefebvre. (aucune date) Ville de Montréal. https://ville.montreal.qc.ca/ordre/en/soeurdenise-lefebvre.

Ville de Montréal (2019). La Ville de Montréal nomme la place centrale du projet MIL Montréal en l'honneur de Mme Alice Girard.

http://ville.montreal.qc.ca/portal/page?_pag eid=5798,42657625\&_dad=portal\&_schem $\underline{\mathrm{a}=\text { PORTAL\&id }=31987}$ 